\title{
Chapter 6 \\ Status and Reform of International Arctic Shipping Law
}

\author{
Erik J. Molenaar
}

\begin{abstract}
The last years have witnessed a continuous decrease in Arctic sea ice coverage and thickness and a significant expansion in the volume of shipping traffic. This chapter assesses the adequacy of the current international legal and policy framework for Arctic shipping in view of the likelihood that these trends continue in coming years. An overview of the international legal and policy framework is provided, the main gaps therein are identified, and options for addressing these are suggested. Options could be undertaken within the International Maritime Organization (IMO) but also outside the IMO, for instance within the Arctic Council or among ad hoc groupings of states. Separate attention is devoted to the potential for cooperation between the European Union and the United States in this regard.
\end{abstract}

\subsection{Introduction}

As future trends in Arctic marine shipping depend to a significant extent on sea ice coverage and thickness, it is important to note that both have been steadily declining. The summer 2012 Arctic sea ice extent was the lowest on record, the

\footnotetext{
Writing this chapter was facilitated by funding from the Netherlands Polar Programme and the EU's COST Action IS1105 'NETwork of experts on the legal aspects of MARitime SAFEty and security (MARSAFENET)'. The author is grateful for comments by Carien Droppers, Henrik Ringbom, Greg O'Brien, and others on an earlier version of the chapter. This chapter builds on Molenaar EJ, Corell R (2009). Background Paper. Arctic Shipping. Arctic TRANSFORM.
}

\section{E. J. Molenaar $(\triangle)$}

Netherlands Institute for the Law of the Sea (NILOS), Utrecht University, Utrecht, The Netherland

Faculty of Law, University of Troms $\varnothing$, Troms $\varnothing$, Norway

e-mail: E.J.Molenaar@uu.nl 
December 2012 sea ice was the second lowest on record, and-perhaps even more important-multi-year sea ice has declined even further after the enormous loss in the summer of 2007. For several summers now, both the Northwest Passage and the Northern Sea Route have been open. ${ }^{1}$

Intra- and trans-Arctic marine shipping can be interesting alternatives for the much longer routes using the Panama and Suez Canals, or for Arctic routes that are partly terrestrial and partly marine. But even though summers without sea ice in much or all of the Arctic Ocean may occur in the not too distant future, sea ice will still be widespread in winter. While much or most of this will be first-year sea ice, there may be other factors that could adversely affect shipping conditions and care must therefore be taken not to overestimate the potential growth of Arctic marine shipping (Kraska 2007; Brigham 2010; ICS 2012). However, even a limited expansion of intra- and trans-Arctic marine shipping requires an assessment of the adequacy of national and international regulation. The 1989 Exxon Valdez disaster has not been forgotten and the 2010 crisis with the Deepwater Horizon in the Gulf of Mexico painfully exposed human failure on numerous counts, including a tendency to underestimate risks. In the summer of 2010, this tendency was also illustrated by two groundings in Canadian waters: a tanker carrying fuel, close to Pangnirtung, and the cruise-vessel Clipper Adventurer, just east of Kugluktuk. ${ }^{2}$

This chapter assesses the adequacy of the current international legal framework for Arctic shipping in light of the current and expected impacts of global climate change on the marine Arctic. The focus is predominantly on the impacts of Arctic marine shipping on the Arctic marine environment and its biodiversity. The maritime safety dimension is covered where regulation serves a significant subsidiary purpose of pollution prevention. Delimiting the scope of this chapter in this way, however, is not meant to suggest that ensuring maritime safety in the marine Arctic is not as important or urgent, particularly in view of the continued and increasing interest in Arctic sea-borne tourism.

After providing some context and background information on current and future Arctic marine shipping in Sect. 6.2, an overview of the international legal and policy framework for Arctic marine shipping is provided in Sect. 6.3. Gaps in the international legal and policy framework and options for addressing them are covered in Sect. 6.4 and the potential for EU-US cooperation is examined in Sect. 6.5. Some conclusions are offered in Sect. 6.6.

For the purposes of this chapter, Arctic marine shipping is regarded as the shipping that occurs or could occur in the marine Arctic. This chapter uses the same definitions for the terms 'marine Arctic', 'Arctic Ocean', 'Arctic states', and 'Arctic Ocean coastal states' as throughout this book. It is worth noting that

\footnotetext{
${ }^{1}$ Information obtained from <nsidc.org/arcticseaicenews $>$, <www.arctic.noaa.gov/reportcard>, and <www.climatewatch.noaa.gov> on 11 Jan 2013.

2 See the press releases and other information at $<$ barentsobserver.com $>$, $<w w w$.arcticmonitor. net>, and <www.institutenorth.org $>$.
} 
the definition of marine Arctic is a broader area than the 'Arctic waters' under the International Maritime Organization (IMO) Polar Shipping Guidelines (2009), as described in Chap. 1.

Arctic marine shipping can be intra-Arctic or trans-Arctic. Trans-Arctic marine shipping can take place by means of various routes and combinations of routes. Two of these routes are the Northwest Passage and the Northern Sea Route. The official Northern Sea Route encompasses all routes across the Russian Arctic coastal seas from Kara Gate (at the southern tip of Novaya Zemlya) to the Bering Strait (Tymchenko 2001). The Northwest Passage is the name given to the marine routes between the Atlantic and Pacific Oceans along the northern coast of North America that span the straits and sounds of the Canadian Arctic Archipelago. Pharand identified seven main routes, with minor variations (Pharand 2007). An alternative to all these routes is the Central Arctic Ocean Route, which runs straight across the middle of the Central Arctic Ocean.

\subsection{Current and Future Arctic Marine Shipping}

While the current volume of Arctic marine shipping is still very modest, recent years have seen steady - and sometimes significant-increases in many types of shipping, including transits through the Northwest Passage and the Northern Sea Route, destinational traffic associated with offshore resource activity, and Arctic sea-borne tourism. As regards transits, various records and first-evers have recently occurred; for instance: back-to-back crossings of both the Northwest Passage and the Northern Sea Route in a single summer by yachts; the transit of the Northwest Passage by The World in the summer of 2012; and-in relation to the Northern Sea Route-tankers carrying oil, gas condensate, and liquid natural gas (LNG); the first ferry (the Georg Ots); the first non-Russian bulk-carrier (the MV Nordic Barents) carrying iron-ore concentrate without stopping at a Russian port; and the first cargo vessel (the Monchegorsk) to transit without ice-breaker assistance. However, regular container ship operations through the Northern Sea Route have not proven commercially viable. ${ }^{3}$

Indications are that traffic in the Northwest Passage will grow much less compared to the Northern Sea Route (AMSA 2009; AOR 2013). This is to some extent caused by projections about the presence of sea ice and natural restraints (e.g., shallowness) in parts of the Northwest Passage. Another important factor is that Russia is much more interested in developing Arctic marine shipping than Canada, and has made large efforts in support of development (Emmerson 2011). In addition to substantial investments in infrastructure, vessels, and equipment, and reforms in domestic legislation and institutional arrangements (Solski 2013),

\footnotetext{
${ }^{3}$ See the press releases and other information at $<$ barentsobserver.com $>$, <www.arcticmonitor. net>, and <www.institutenorth.org >
} 
reference can be made to the strategic agreement adopted in 2010 between the Sovcomflot Group and the China National Petroleum Corporation, which envisions increased usage of the Northern Sea Route. ${ }^{4}$ The 'shale gas revolution' has also meant that Russian gas originally intended to be shipped to the east coast of the United States (US), is now shipped through the Northern Sea Route to China and other Asian states. This is a good example of the role of key variables, uncertainties, or 'wildcards' in the scenarios developed as part of the Arctic Marine Shipping Assessment (AMSA). Examples of wildcards are an accelerated Arctic meltdown, major Arctic shipping disasters, and technology breakthroughs (AMSA Scenarios 2008). The risk assessments of classification societies and the marine insurance industry are also likely to be a crucial factor for the economic viability of all Arctic marine shipping.

Due to the accelerated melting of Arctic sea ice, the Central Arctic Ocean Route may soon be an option as well (Humpert and Raspotnik 2012). The most suitable course of this latter route may vary from year to year and lead to various combinations of the Central Arctic Ocean Route on the one hand and the Northwest Passage and Northern Sea Route on the other hand. Some of the routes of which the Northern Sea Route consists already pass through the high seas area of the Central Arctic Ocean. It is finally important to note that all trans-Arctic marine shipping must pass through the Bering Strait.

Marine shipping has the following actual and potential impacts on the marine environment and marine biodiversity:

1. Shipping practices and incidents leading to accidental discharges of polluting substances (cargo or fuel) or physical impact on components of the marine ecosystem (e.g., on the benthos and larger marine mammals);

2. Operational discharges (cargo residues, fuel residues (sludge), (incineration of) garbage and sewage), and emissions;

3. Introduction of alien organisms through ballast-water exchanges or attachment to vessel hulls (e.g., in crevices); and

4. Other navigation impacts (noise pollution and other forms of impacts on, or interference with, marine species potentially causing, for instance, disruption of behaviour, abandonment, or trampling of the young by fleeing animals or displacement from normal habitat).

All these actual and potential impacts are also relevant for Arctic marine shipping. The likelihood for some of these impacts-for instance shipping incidents - to occur is higher in some parts of the marine Arctic due to the presence of ice(bergs), lack of accurate charts, and in the case of insufficient experience in navigating in ice-covered areas. In addition, cold temperatures may affect machinery, and icing can create additional loads on the hull, propulsion systems, and appendages (VanderZwaag et al. 2008). The remoteness of much of the marine Arctic, the limited available maritime safety information data, and the challenges

\footnotetext{
${ }^{4}$ See the press release of 22 Nov 2010 at <www.sovcomflot.ru>.
} 
of navigating therein moreover mean that once shipping incidents do occur, a response will take a relatively long time and may even then be inadequate to address impacts on the marine environment and marine biodiversity.

\subsection{International Legal and Policy Framework for Arctic Marine Shipping}

\subsubsection{Interests, Rights, Obligations, and Jurisdiction}

The international legal and policy framework for vessel-source pollution seeks to safeguard the different interests of the international community as a whole with those of states that have rights, obligations, or jurisdiction in their capacities as flag, coastal, or port states or with respect to their natural and legal persons. While the term 'flag state' is commonly defined as the state in which a vessel is registered and/or whose flag it flies (LOS Convention 1982, art. 91(1)), there are no generally accepted definitions for the terms 'coastal state' or 'port state'. For the purposes of this chapter, however, the term 'coastal state' refers to the rights, obligations, and jurisdiction of a state within its own maritime zones over foreign vessels.

The term 'port state' refers to the rights, obligations, and jurisdiction of a state over foreign vessels that are voluntarily in one of its ports. In order to avoid an overlap with jurisdiction by coastal states, this chapter regards port state jurisdiction as relating to illegal discharges by foreign vessels beyond the coastal state's maritime zones as well as over violations of conditions for entry into port (Molenaar 2007).

The balance in the above-mentioned framework is first of all between the socioeconomic interests of flag states in unimpeded navigation and a minimum of globally uniform international regulation, and the environmental interests of the coastal state. The port state commonly seeks to balance its local environmental interests and the broader environmental interests that 'its' coastal state has over its maritime zones, against the socioeconomic interests of the port and its hinterland. States generally have interests, rights, obligations, and jurisdiction in more than one capacity. This commonly leads to a more balanced compromise position, but occasionally also to contradictory positions of the same state within different fora. There is no reason or indication to assume that Arctic states are different in this regard.

The interests of the international community-e.g., sustainable utilization, protection, and preservation of the marine environment, and conservation of marine biodiversity - normally overlap with those of flag, coastal, and port states, but are usually broader and more general. The interests of some states, however, clearly undermine those of other states and the international community, for instance, by not ensuring that their ships comply with international minimum standards or by allowing foreign vessels in their ports to be non-compliant with international minimum standards. These states, vessels, and ports thereby have a com- 
petitive advantage over states, vessels, and ports that do comply with international minimum standards. Such 'free riders' clearly benefit from the consensual nature of international law-meaning that a state can only be bound to a rule of international law when it has in one way or another consented to that rule.

\subsubsection{Substantive Shipping Standards}

The categories of substantive shipping standards below are based on the substantive focus of this chapter (see Sect. 6.1), the LOS Convention's (1982) jurisdictional framework for vessel-source pollution, and practice within IMO so far. The categories are:

1. Discharge and emission standards, including standards relating to ballast water exchange;

2. Construction, design, equipment, and manning (CDEM) standards, including fuel content specifications and anti-fouling and ballast water treatment standards;

3. Navigation standards, in the form of ships' routeing measures, ship reporting systems (SRSs), and vessel traffic services (VTS);

4. Contingency planning and preparedness standards; and

5. Liability, compensation, and insurance requirements.

This categorization is merely meant to facilitate the discussion below, however. It does not capture the entire spectrum of types of standards or requirements developed within IMO or applied by individual states acting in their various capacities. An Arctic Ocean coastal state may for instance require use of ice-breaker assistance and the payment of fees for such services.

\subsubsection{Global and Regional Bodies}

International regulation of vessel-source pollution by merchant ships is primarily done by global bodies. While IMO is the most prominent, the International Labour Organization (ILO) and the International Atomic Energy Agency (IAEA) adopt relevant regulation as well. The pre-eminence of global bodies is a direct consequence of the global nature of international shipping and the interest of the international community in globally uniform international minimum regulation (VanderZwaag et al. 2008; Chircop 2009; Molenaar 2010). The LOS Convention safeguards this by allowing unilateral coastal state prescription in only a few situations. These exceptions are explained in Sect. 6.3.4, which also devotes attention to so-called 'residual port state jurisdiction'.

As unilateral coastal state prescription and residual port state jurisdiction can also be exercised collectively (in concert), regional regulation of marine shipping by regional bodies or ad-hoc groupings of states is not inconsistent with the 
LOS Convention, and thereby also not with the primary role accorded to the IMO by the LOS Convention (Stokke 2012). Regional regulation can also be pursued on an inter se basis to ships flying the flag of parties-for instance, Annex IV on 'Prevention of Marine Pollution' to the Antarctic Treaty's (1959), Protocol on Environmental Protection (1991).

Several IMO instruments also allow or encourage regional implementation. This has led the Arctic Council to undertake efforts to implement IMO's SAR (Search and Rescue) Convention (1979) by means of the Arctic SAR Agreement (2011), and IMO's OPRC 90 (1990) by means of the future Arctic MOPPR (Marine Oil Pollution Preparedness and Response) Agreement (2013), which is scheduled to be signed at the Arctic Council's Ministerial Meeting in Kiruna in May 2013.

Regional action within the broad spectrum of monitoring, surveillance, inspection, and enforcement is consistent with the LOS Convention as well, even though the Convention does not explicitly encourage it. IMO has frequently encouraged such regional action, for instance by means of the 1991 IMO Assembly Resolution A.682(17) 'Regional Co-operation in the Control of Ships and Discharges', which triggered the creation of a global network of regional arrangements on port state control (PSC) modelled on the then already almost decade-old Paris MOU Convention (1982).

The IMO bodies of most relevance to this chapter are the Marine Environment Protection Committee (MEPC), the Maritime Safety Committee (MSC), and the latter's Sub-Committee on Navigation (NAV) and its Sub-Committee on Design and Equipment (DE). Amendments to MARPOL 73/78 (1973/1978) are adopted by the MEPC and amendments to SOLAS 74 (1974) by the MSC. The MEPC has a coordinating role in relation to particularly sensitive sea areas (PSSAs) and the MSC has the authority to adopt mandatory SRSs and VTS pursuant to the SOLAS 74 and COLREG 72 (1972). Proposals for many of the associated protective measures (APMs) that are made applicable within PSSAs are first discussed in the NAV. The ongoing process to develop a mandatory Code for Shipping in Polar Waters (Polar Code) takes predominantly place within DE.

Other bodies relevant to Arctic marine shipping are the International Association of Classification Societies (IACS) - in particular on account of its Unified Requirements concerning Polar Class -, the Association of Arctic Expedition Cruise Operators (AECO), the Arctic Council-in particular through the efforts of its Protection of the Arctic Marine Environment (PAME) and Emergency, Prevention, Preparedness, and Response (EPPR) working groups -, and the OSPAR Commission.

\subsubsection{Global and Regional Instruments}

\section{LOS Convention}

Most of the LOS Convention's provisions on vessel-source pollution are laid down in its Part XII, entitled 'Protection and Preservation of the Marine Environment'. This part begins with Chap. 1, entitled 'General Provisions' and applies to all 
sources of pollution. Its first provision, Article 192 lays down the general obligation for all states - in whatever capacity therefore- "to protect and preserve the marine environment". This is elaborated in Article 194 with regard to measures to prevent, reduce, and control pollution of the marine environment; aimed specifically at vessel-source pollution in paragraph (3)(b). Other relevant general obligations relate to rare or fragile ecosystems and the habitat of endangered species (art. 194(5)), introduction of alien species (art. 196), cooperation on a global or regional basis (art. 197), contingency plans against pollution (art. 199), monitoring of the risks or effects of pollution (art. 204), and assessment of potential effects of activities (art. 206). Sections 5 and 6 of Part XII contain separate provisions on prescription and enforcement for all each of the sources of pollution.

The jurisdictional framework relating to vessel-source pollution laid down in the LOS Convention is predominantly aimed at flag and coastal states. Apart from one explicit provision (art. 218), port state jurisdiction is only implicitly dealt with (see 'Port state jurisdiction' below).

Prescriptive jurisdiction by flag and coastal states is linked by means of rules of reference to the notion of 'generally accepted international rules and standards' (GAIRAS). These refer to the technical rules and standards laid down in instruments adopted by regulatory bodies, in particular IMO. It is likely that the rules and standards laid down in legally binding IMO instruments that have entered into force can at any rate be regarded as GAIRAS (Molenaar 1998).

The basic duty for flag states to exercise effective jurisdiction and control over ships flying their flag laid down in Article 94 of the LOS Convention is further specified in Article 211(2), which stipulates that flag state prescriptive jurisdiction over vessel-source pollution is mandatory and must at least have the same level as GAIRAS. It is therefore up to flag states to require their vessels to comply with more stringent standards than GAIRAS, but this will of course impact their competitiveness.

This mandatory minimum level of flag state jurisdiction established by the LOS Convention is balanced by according all states the following navigational rights:

1. The right of innocent passage-suspendable or non-suspendable -, in territorial seas, archipelagic waters outside routes normally used for international navigation or-if designated-archipelagic sea lanes, internal waters pursuant to Article 8(2) of the LOS Convention, and certain straits used for international navigation;

2. The right of transit passage in straits used for international navigation;

3. The right of archipelagic sea lanes passage within routes normally used for international navigation or-if designated — archipelagic sea lanes; and

4. The freedom of navigation within exclusive economic zones (EEZs) and on the high seas.

Coastal state prescriptive jurisdiction over vessel-source pollution is optional under the LOS Convention but, if exercised, cannot be more stringent than the level of GAIRAS (LOS Convention 1982, arts. 21(2), 39(2) and 211(5)). This is the general rule even though it is subject to some exceptions that are discussed further below. 


\section{Straits Used for International Navigation}

The general rule just mentioned is also applicable to marine areas where the right of transit passage applies (LOS Convention 1982, arts. 41 and 42(1)(a) and (b)). This regime was developed for narrow international straits that would no longer have a high seas corridor once strait states would extend the breadth of their territorial seas to 12 nautical miles (nm). The applicability of the regime of transit passage is nevertheless dependent on various conditions.

One of these is laid down in Article 37 and stipulates that the regime of transit passage only applies to "straits which are used for international navigation". Diverging views exist on the words "are used", where the normal meaning points to 'actual' and not 'potential' usage. The latter is adhered to by the US, which takes the view that "the term 'used for international navigation' includes all straits capable of being used for international navigation" (Sen. Exec. Rep. 110-9 2007). Conversely, Canada and the Russian Federation take the view that the words refer to actual usage, and most commentators embrace this interpretation as well (e.g., Rothwell 1996; Pharand 2007). Close reading of the ICJ's Judgment in the Corfu Channel case ${ }^{5}$-from which the phrase originates-nevertheless reveals that it also touches on potential usage (cf. McDorman 2010).

Consistent with its above view on potential usage, the US regards the Northwest Passage and parts of the Northern Sea Route as straits used for international navigation subject to the regime of transit passage (NSPD-66 2009). None of the European Union's (EU) Arctic policy statements in recent years contain a position on the issue, even though the EU Council of the European Union's Conclusions on Arctic issues (Council of the European Union 2009) mention transit passage. However, one would assume that at least some states with large fleets engaged in international shipping or with a special interest in Arctic shipping-for instance China, Japan, Norway, South Korea, and several EU Member Statesshare the view of the US.

Consistent with its above view on actual usage, Canada does not regard the Northwest Passage as a strait used for international navigation. Canada combines this position with two other positions. First, the waters within its Arctic archipelago enclosed by its 1985 straight baselines ${ }^{6}$ are internal waters based on historic title (CYIL 1987, 1988). As a corollary, the right of innocent passage pursuant to Article 8(2) of the LOS Convention does not apply (Lalonde 2004). Both the US and the then European Community (EC) Member States lodged diplomatic protests against the 1985 straight baselines, regarding them as inconsistent with international law and explicitly rejecting that historic title could provide an adequate justification (Roach and Smith 1996). The second position that Canada combines

\footnotetext{
${ }^{5}$ Corfu Channel case (United Kingdom of Great Britain and Ireland v. Albania), Judgment on the Merits of 9 Apr 1949, ICJ Reports 1949, p. 1.

6 Territorial Sea Geographical Coordinates (Area 7) Order, S.O.R./85-872; effective on 1 Jan 1986.
} 
with its view on the Northwest Passage is that the transit passage regime is trumped by Article 234 of the LOS Convention (see Section 'Unilateral Coastal State Prescription').

Despite their bilateral Agreement on Arctic Cooperation (1988), the dispute between Canada and the US on the legal status of the Northwest Passage and the applicable regime of navigation remains unresolved. The broad saving-clause included in its Sect. 6.4 indicates that the agreement should above all be regarded as an 'agreement-to-disagree'. The 2010 debates within IMO on Canada's mandatory Northern Canada Vessel Traffic Services (NORDREG) Regulations (SOR/2010-127)—which focus predominantly on Article 234 of the LOS Convention, however-are further proof that their disputes remain unresolved (see 'Unilateral coastal state prescription' below).

The position of the Russian Federation vis-à-vis the Northern Sea Route seems largely similar to that of Canada and consists of combined positions on actual usage, internal waters included within straight baselines pursuant to historic title, and transit passage being trumped by Article 234 (Brubaker 1999; Brubaker 2001).

\section{General Exceptions}

The above-mentioned restriction on coastal state jurisdiction applies only in relation to pollution of the marine environment, as defined in Article 1(1)(4) of the LOS Convention. Once coastal state jurisdiction is not exercised for that purpose but, for instance, for the conservation of marine living resources instead, the general rule on coastal state jurisdiction over vessel-source pollution does not apply either. As regards anchoring, this view is supported by the practice of the US and-more recently - the Netherlands on regulating anchoring beyond the territorial sea without seeking IMO approval and apparently without any objection by other states. As regards ballast water discharges, the above view is supported by the fact that, instead of an Annex to MARPOL 73/78, IMO decided to deal with ballast water management in a stand-alone treaty, namely the BWM Convention (2004). Moreover, the BWM Convention allows states individually or in concert to regulate more stringently above the minimum ballast water exchange level laid down in the Convention (BWM Convention 2004, arts. 2(3) and 13(3) and Section $\mathrm{C}$ of the Annex).

More stringent standards can also be adopted for special areas pursuant to Article 211(6) of the LOS Convention. But as this requires at any rate IMO approval, it gives coastal states no unilateral prescriptive authority. The PSSA Guidelines (IMO 2005) developed by IMO also implement Article 211(6) and are clearly inspired by, and consistent with, that provision (IMO 2005, para. 7.5.2.3(iii)). PSSA status is not a precondition for obtaining the majority of possible APMs as, for instance, ships' routeing measures, SRSs, or VTS can also be made applicable to the maritime zones of a coastal state upon its request by means of IMO approval. 


\title{
Unilateral Coastal State Prescription
}

There are three exceptions to the abovementioned general rule that coastal state prescription cannot be more stringent than GAIRAS. First, as general international law does not grant foreign vessels any navigational rights in internal waters - apart from a minor exception laid down in Article 8(2) of the LOS Convention-coastal state jurisdiction is in principle unrestricted. The observations on port state jurisdiction below applies therefore mutatis mutandis to internal waters.

Second, a coastal state is entitled to prescribe more stringent (unilateral) standards for the territorial sea, provided they "shall not apply to the design, construction, manning or equipment of foreign ships unless they are giving effect to generally accepted international rules or standards" (LOS Convention 1982, art. 21(2)). Unilateral discharge, navigation, and ballast water management standards are, among others, allowed. The rationale of this provision is to safeguard the objective of globally uniform international minimum regulation, which would be undermined if states unilaterally prescribe standards that have significant extraterritorial effects.

A third exception is laid down in Article 234 of the LOS Convention. It is entitled 'Ice-covered areas' and provides:

\begin{abstract}
Coastal States have the right to adopt and enforce non-discriminatory laws and regulations for the prevention, reduction and control of marine pollution from vessels in ice-covered areas within the limits of the exclusive economic zone, where particularly severe climatic conditions and the presence of ice covering such areas for most of the year create obstructions or exceptional hazards to navigation, and pollution of the marine environment could cause major harm to or irreversible disturbance of the ecological balance. Such laws and regulations shall have due regard to navigation and the protection and preservation of the marine environment based on the best available scientific evidence.
\end{abstract}

Article 234 was included in the LOS Convention as a result of in particular the efforts of Canada, which sought to ensure that its Arctic Waters Pollution Prevention Act (AWPPA 1970) and underlying regulations and orders would no longer be regarded as inconsistent with international law. The negotiations on Article 234 were predominantly conducted by Canada, the Soviet Union, and the US and were closely connected to what eventually became Article 211(6) on special areas (McRae 1987; Huebert 2001; Bartenstein 2011).

While Article 234 contains a number of ambiguities-not unlike many other provisions in the LOS Convention, and in fact many treaties-the basic purpose is to provide a coastal state with broader prescriptive and enforcement jurisdiction in ice-covered areas than in maritime zones elsewhere. In particular, in contrast with Article 211(6) on special areas, Article 234 does not envisage a role for the 'competent international organization' (IMO) in case the coastal state takes the view that more stringent standards than GAIRAS are needed.

As the wording of Article 234 indicates, however, jurisdiction is subject to several restrictions and can only be exercised for a specified purpose. One such restriction follows from the words "for most of the year". Decreasing ice coverage will mean that, gradually, fewer states will be able to rely on Article 234 in fewer 
areas. As regards the phrase "within the limits of the exclusive economic zone", it is submitted that the better interpretation is that this is merely meant to indicate the outer limits of the EEZ but not to exclude the territorial sea (Molenaar 1998).

The purpose for which jurisdiction can be exercised pursuant to Article 234 is "the prevention, reduction and control of marine pollution from vessels". Even though 'navigation' is mentioned twice in Article 234, it does not explicitly grant jurisdiction for the purpose of ensuring maritime safety. It is nevertheless submitted that Article 234 allows regulations that have environmental protection as a primary purpose and maritime safety as a secondary purpose as well as regulations for which both purposes are more or less equally important.

The LOS Convention does not explicitly address the scenario of waters that are both ice-covered and subject to the regime of transit passage, but many commentators argue that the inclusion of the stand-alone Article 234 in the separate Sect. 8 of Part XII supports the dominance of Article 234 over transit passage (Hakapää 1981; McRae 1987; Pharand 2007). While the International Chamber of Shipping (ICS) supports the opposite view (ICS 2012), the US does not seem to have ever explicitly and publicly stated that transit passage trumps Article 234, even though this might well be its position (Roach and Smith 1996; contra McDorman 2010). There may be several reasons for this, including the fact that the US is not a party to the LOS Convention, awareness that its position is not very strong, and a preference for a cooperative rather than a confrontational stance.

The following states would currently be entitled to exercise jurisdiction pursuant to Article 234: Canada, Denmark (in relation to Greenland), Norway [in relation to Svalbard but subject to the Spitsbergen Treaty (1920)], the Russian Federation, and the US. So far only Canada and the Russian Federation have actually exercised such jurisdiction (Franckx 1993; Brubaker 2005; VanderZwaag et al. 2008; Solski 2013). The Kingdom of Denmark's 'Strategy for the Arctic' (2011) refers to Denmark's willingness to invoke Article 234 when adequate standards cannot be adopted within IMO.

The consistency of the national laws and regulations of Canada and the Russian Federation with international law has been questioned from time to time. For instance: the applicability of certain CDEM standards to foreign warships and other governmental vessels (re Canada); discriminatory navigation requirements, icebreaker fees, and insurance requirements; lack of transparency; and high levels of bureaucracy (primarily re Russian Federation, even if not stated) (Molenaar et al. 2010; ICS 2012; Solski 2013).

The consistency of Canada's NORDREG Regulations with Article 234 of the LOS Convention was debated within IMO's NAV (56th Session) ${ }^{7}$ and MSC (88th Session) ${ }^{8}$ in 2010 (McDorman 2012). Canada introduced the voluntary NORDREG system in 1977 but decided to make it mandatory as a consequence of Canada's

\footnotetext{
7 IMO doc. NAV 56/20, of 31 Aug 2010, at paras 19.21-19.24.

8 IMO docs MSC 88/11/2, of 22 Sept 2010; MSC 88/11/3, of 5 Oct 2010; MSC 88/26, of 15 Dec 2010, at paras 11.28-11.39 and Annexes 27 and 28.
} 
Northern Strategy (Minister of Indian Affairs and Northern Development 2009). The NORDREG Regulations became mandatory on 1 July 2010 within the extended $(200 \mathrm{~nm})$ scope of the AWPPA, and therefore have a much wider scope than the Northwest Passage. The cornerstone of the NORDREG Regulations is the requirement for prescribed vessels - whether domestic or foreign — to submit, prior to entering the NORDREG Zone, certain information and to obtain clearance. ${ }^{9}$ Contravention of these requirements could lead to the vessel's detention and the imposition of a fine and/or imprisonment (c.f. Canada Shipping Act 2001, sec. 138), but none of these seem to have been imposed so far. The NORDREG Regulations are enacted pursuant to the Canada Shipping Act (2001), whose objectives include marine environmental protection (sec. 6).

At MSC 88, the debate centred mainly around the question whether or not Canada was required to seek IMO approval before imposing the NORDREG Regulations on foreign vessels. The US argued that IMO approval was necessary because in its view SOLAS 74 and associated guidelines do not provide an adequate basis for imposing the NORDREG Regulations unilaterally. The US made no references to Article 234 or even the international law of the sea, even though it made the latter references at NAV 56 and its diplomatic notes to Canada (McDorman 2013). The NORDREG Regulation's requirement to obtain clearance is probably the most troublesome for the US, among other things because it essentially amounts to the need for prior authorization and could have precedentsetting effects for other waters that the US regards as straits used for international navigation.

The US was in particular supported by interventions from Germany and Singapore at MSC 88. While the former closely followed the US position at MSC 88, the latter explicitly viewed Canada's actions as inconsistent with the LOS Convention. Prior to MSC 88, France, Germany, and the United Kingdom-and presumably other states as well-had sent Notes Verbales to Canada. Before the United Kingdom issued its Note Verbale, it approached the European Commission to verify if the Commission would be willing to issue a Note Verbale. The Commission declined, in part because it felt that it was not evident that Canada's actions warranted a diplomatic protest and in part also due to concerns that a diplomatic protest could compromise the EU's more important interests in cooperation with Arctic states within and outside the Arctic Council. ${ }^{10}$

Canada - supported among others by Norway and the Russian Federationtook the view that IMO approval was unnecessary as Article 234 provided an adequate basis. While the debates at NAV 56 and MSC 88 were inconclusive and did not resurface within IMO, they illustrate that many more states than just the US

${ }^{9}$ Cf. sec. 4 of the NORDREG Regulations (SOR/2010-127); Canada Shipping Act 2001, sec. 126(1)(a); and IMO doc. SN.1/Circ.291, of 5 Oct 2010, 'Information on the Mandatory Canadian Ship Reporting System in Canada's Northern Waters (NORDREG)'.

10 Based on communications between the author and officials from Germany, France, the United Kingdom, and the Commission in late 2010 and early 2011. 
are concerned about navigational rights and coastal state jurisdiction over shipping in ice-covered areas and potential precedent-setting effects for straits used for international navigation.

\section{Port State Jurisdiction}

As ports lie wholly within a state's territory and fall on that account under its territorial sovereignty, customary international law acknowledges that a port state has wide discretion in exercising jurisdiction over its ports. This was explicitly stated by the International Court of Justice (ICJ) in the Nicaragua case where it observed that it "by virtue of its sovereignty, that the coastal state may regulate access to its ports". 11 While there may often be a presumption that access to port will be granted, customary international law gives foreign vessels no general right of access to ports (Lowe 1977). Articles 25(2), 211(3), and 255 of the LOS Convention implicitly confirm the absence of a right of access for foreign vessels to ports as well as the port state's wide discretion in exercising jurisdiction under customary international law. This socalled 'residual' jurisdiction is also recognized in several IMO instruments and has on some occasions been exercised by the US and the EU. Nevertheless, some exceptions apply_for instance in case of force majeure and distress - and uncertainties exist-for instance on the implications of international trade law. International law only very rarely authorizes port states to impose enforcement measures that are more stringent than denial of access or use of port (services) for extra-territorial behaviour (Molenaar 2007). Article 218 of the LOS Convention is one of these instances. This innovative provision gives port states enforcement jurisdiction over illegal discharges beyond their own maritime zones, namely the high seas and the maritime zones of other states.

\section{IMO Instruments}

In view of the focus of this chapter (see Sect. 6.1) and the main categories of substantive shipping standards listed in Sect. 6.3.2, the following are the most important legally binding IMO instruments:

1. MARPOL 73/78;

2. SOLAS 74;

3. STCW 78 (1978);

4. The Anti-Fouling Convention (2001);

5. The BWM Convention (2004);

6. COLREG 72;

11 Case concerning Military and Paramilitary Activities In and Against Nicaragua (Nicaragua v. United States of America), Judgment of 27 June 1986, ICJ Reports 1986, p. 14. 
7. OPRC 90 and its HNS Protocol (2000);

8. The various IMO instruments relating to liability, compensation, and insurance, e.g., the Civil Liability Convention (1969), the Fund Convention (1971) (each modified by several protocols), the HNS Convention (1996), and the Bunker Oil Convention (2001).

In addition, the following are the most important non-legally binding IMO instruments:

1. The General Provisions on Ships' Routeing (IMO 1985);

2. The MARPOL 73/78 Special Area Guidelines (IMO 2001);

3. The PSSA Guidelines (IMO 2005);

4. The Arctic Shipping Guidelines (2002); and

5. The Polar Shipping Guidelines (2009).

Apart from the Arctic and Polar Shipping Guidelines, all these legally binding and non-legally binding instruments have a global scope of application and therefore apply in principle to the entire marine Arctic. As is illustrated below, however, many IMO instruments allow for the adoption of more stringent measures in specified geographical areas. It should also be noted that where Arctic states are not parties to certain legally binding IMO instruments, they will not implement them in any capacity, including as a coastal state.

The remainder of this subsection will elaborate further on (a) discharge and emission standards, (b) CDEM standards, (c) navigation standards, (d) PSSA Guidelines, and (e) other standards.

\section{Discharge and Emission Standards}

MARPOL 73/78 and the BWM Convention are the only IMO instruments that contain discharge and emission standards. The Annexes to MARPOL 73/78 contain discharge standards for oil (Annex I), noxious liquid substances (Annex II), sewage (Annex IV), and garbage (Annex V), and emission standards for ozone depleting substances, nitrogen oxides (NOx), sulphur oxides (SOx), and volatile organic compounds (VOCs) (Annex VI). Annexes I, II, IV, and V allow the designation of so-called 'special areas' where more stringent discharge standards apply. Annex VI allows the designation of so-called 'Emission Control Areas' for SOx, particulate matter, and NOx. A substantial number of special areas and Emission Control Areas are currently in effect, but none of these apply to the marine Arctic.

The BWM Convention stipulates that vessels using the ballast water exchange method should not discharge ballast water within $200 \mathrm{~nm}$ from the nearest land or in waters less than 200 metres deep and must meet an efficiency of at least $95 \%$ volumetric exchange (Regulations B-4 and D-1). Also, as was noted above, the BWM Convention allows states individually or in concert to regulate more stringently above this minimum level. 


\section{CDEM Standards}

CDEM standards are contained in many of the main legally binding IMO instruments, in particular SOLAS 74 and STCW 78. The well-known double-hull standard-which was triggered by the Exxon Valdez disaster in 1989-is nevertheless laid down in Annex I to MARPOL 73/78. Arguably, the fuel content requirements in Annex VI to MARPOL 73/78 (within and beyond Emission Control Areas) and the ballast water treatment requirements in the BWM Convention must be regarded as, or treated analogous with, CDEM standards. A similar argument could be made for prescriptions on the use of certain paints or coatings pursuant to the Anti-Fouling Convention. A recent amendment to the STCW Code connected to STCW 78 concerns the inclusion of a new (voluntary) Section B-V/g on 'Guidance regarding training of Masters and officers for ships operating in Polar waters'.

As the Polar Shipping Guidelines are envisaged to be replaced by the Polar Code, it will only be briefly mentioned here. The Polar Shipping Guidelines are more elaborate and extensive than the Arctic Shipping Guidelines, for instance in relation to life-saving appliances. The Polar Shipping Guidelines contain the definition of 'ship' used in SOLAS 74 and apply to all voyages in Antarctic waters but as regards Arctic waters only to international voyages. They contain mostly CDEM standards and strong links with the IACS Unified Requirements concerning Polar Class.

The Polar Code is still under development and at least two more years beyond its original target of 2012 are needed until its adoption. The Code's maritime safety component is in a more advanced stage than the marine pollution component. ${ }^{12}$ Slow progress on the Code is at least in part caused by complexities on the linkage between the Code and other IMO instruments, and a failure to select one of the available options early on. Apart from SOLAS 74 and MARPOL 73/78, there also seems to be support for including linkages with other IMO 'pollution' instruments such as the Anti-fouling Convention and the BWM Convention. At MSC 91 in November 2012, it was confirmed that all relevant IMO instruments "should be amended to mandate the associated provisions of the future Polar Code, as opposed to making it mandatory under the SOLAS Convention only or developing a stand-alone new Convention". ${ }^{13}$ It is submitted that, if pursued, this approach would make the Polar Code the first genuine regional legally binding IMO instrument. Despite its being bi-polar, it would clearly be much broader and more comprehensive than, for instance, special areas and Emission Control Areas under MARPOL 73/78, or the packages of APMs under PSSAs. The preferred approach may also imply that the special area designations for Antarctica under the Annexes to MARPOL 73/78 will eventually be transferred to the Polar Code.

\footnotetext{
12 The most recent publicly available version seems to be contained in IMO doc. DE 56/WP.4, of 16 Feb 2012.

13 IMO doc. MSC 91/WP 1, of 29 Nov 2012, at para. 8.2.
} 


\section{Navigation Standards}

As noted in Sect. 6.3.2, the category of navigation standards includes ships' routeing measures, SRSs, and VTS. These navigation standards can be adopted by the MSC based on their authority under SOLAS 74 and COLREG 72. As regards ships' routeing measures, reference should be made to the General Provisions on Ships' Routeing. Examples of routeing measures are: traffic separations schemes, deepwater routes, precautionary areas, areas to be avoided, and no anchoring areas. Apart from the regulation of anchoring for the purpose of the conservation of marine living resources, the LOS Convention does not authorize coastal states to adopt mandatory navigation standards seaward of its territorial sea without IMO approval.

While several IMO navigation standards currently apply within the marine Arctic, there is no comprehensive mandatory or voluntary IMO ships' routeing system for the Arctic Ocean or a large part thereof.

\section{PSSA Guidelines}

Designation of an area as a PSSA pursuant to the PSSA Guidelines does not bring about regulation of shipping within that area as such. This requires adoption of one or more APMs. Attention can in this context be drawn to the possibility to have special discharge standards within PSSAs (other than by means of designation as special area under MARPOL 73/78) and "other measures aimed at protecting specific sea areas against environmental damage from ships, provided that they have an identified legal basis" (IMO 2005, para. 6.1.3). Innovative standards are therefore not ruled out.

\section{Other Standards}

Reference should also be made to IMO Assembly Resolution A.999(25), 'Guidelines on voyage planning for passenger ships operating in remote areas' (IMO 2008), that was adopted a week after the tragic sinking of the MS Explorer-a purpose-built, ice-strengthened tourist vessel originally named MS Lindblad Explorer-on 23 November 2007 in Antarctic waters. IMO Assembly Resolution A.999(25) complements the more general IMO Assembly Resolution A.893(21), 'Guidelines for voyage planning' (IMO 1999). Resolution A.999(25) refers, inter alia, to the need to take account of shortcomings in available hydrographic data, the presence of places of refuge, and the need of experience in navigating in ice-covered areas. As regards places of refuge, IMO Assembly Resolution A.949(23), of 5 December 2003, 'Guidelines on Places of Refuge for Ships in Need of Assistance', adopted in the aftermath of the disaster with the Prestige in 2002, is also relevant. Finally, mention should be made of Regulation V/5 of SOLAS 74 on 'Meteorological services and warnings', Regulation V/6 on 'Ice Patrol Service', and Chapter V's Appendix on 'Rules for the management, operation and financing of the North Atlantic Ice Patrol'. 


\section{Regional PSC Arrangements}

Regional PSC Arrangements for merchant shipping were established to enhance compliance with internationally agreed standards by means of commitments to carry out harmonized and coordinated inspections and to take predominantly corrective enforcement action (i.e., detention for the purpose of rectification). The instruments in which these internationally agreed standards are contained are commonly referred to as the 'relevant instruments' and include all the main IMO instruments. A participating Maritime Authority must only apply standards that are not just in force generally but also for that Maritime Authority. ${ }^{14}$ Some applicability gaps therefore remain unavoidable.

The Arrangements are non-legally binding and, rather than states as such, maritime authorities are parties to them (Molenaar 2007). Saving-clauses have nevertheless been incorporated to ensure that nothing in them affects residual port state jurisdiction, which would include the right to take more onerous enforcement measures. ${ }^{15}$

The expansion in participation in the Paris MOU and the creation and expansion of eight new regional PSC Arrangements since then means that almost complete global coverage has now been achieved. However, no Arrangements have been adopted specifically for the Arctic Ocean/region or the Southern Ocean/ Antarctic region. Some advantages and disadvantages of an Arctic Ocean/region MOU will be discussed under Sect. 6.4.2, among other things in view of the likelihood that practically all ships engaged in either intra- or trans-Arctic marine shipping will make use of ports subject to either the Paris MOU or Tokyo MOU Tokyo (1993). None of the other Arrangements seem therefore relevant for Arctic marine shipping. However, when considering amendments to the Paris MOU it is,- -in light of the EU's Directive on Port State Control (2009) and the need of convergence between the Directive and the Paris MOU ${ }^{16}$ - essential to obtain prior agreement within the EU.

The maritime authorities of the following 27 states currently participate in the Paris MOU:

\begin{tabular}{lllll}
\hline Belgium & Estonia & Ireland & Norway & Spain \\
Bulgaria & Finland & Italy & Poland & Sweden \\
Canada & France & Latvia & Portugal & United Kingdom \\
Croatia & Germany & Lithuania & Romania & \\
Cyprus & Greece & Malta & Russian Federation & \\
Denmark & Iceland & Netherlands & Slovenia & \\
\hline
\end{tabular}

14 Cf. Paris MOU, sec. 2.3, and Tokyo MOU (1993), sec. 2.4.

15 E.g., of the Paris MOU, secs. 1.7 and 9.1.

16 See the 13th preambular paragraph of the Directive. 
The participation by the Danish Maritime Authority extends to Greenland as well. Moreover, even though the US Coast Guard merely has observer status, it has been cooperating with the Paris MOU since at least 1986-when it first attended meetings within the Paris MOU-and its PSC system is more or less compatible with that of the Paris MOU. ${ }^{17}$

The Paris MOU does not contain a provision that explicitly defines its spatial coverage. However, Sect. 9.2 stipulates that adherence is open for "A Maritime Authority of a European coastal state and a coastal state of the North Atlantic basin from North America to Europe". This has facilitated the participation or cooperation of the Maritime Authorities of all Arctic states, even though the description is not intended to encompass the entire marine Arctic.

As the Maritime Authorities of both Canada and the Russian Federation also participate in the Tokyo MOU (see below)_and, in addition, the Maritime Authority of the Russian Federation also participates in the Black Sea MOU (2000)-, clarity is needed as to which of their ports are subject to which Arrangement. In 2009, Canada decided to also subject its Pacific ports to the Paris MOU. The Pacific ports of the Russian Federation are currently still subject to the Tokyo MOU, even though some Paris MOU requirements, for instance on training for PSC officers, are applicable throughout the Russian Federation. ${ }^{18}$

The Maritime Authorities of the following states currently participate in the Tokyo MOU:

\begin{tabular}{lllll}
\hline Australia & Fiji & Republic of Korea & Philippines & Thailand \\
Canada & Hong Kong, China & Malaysia & Russian Federation & Vanuatu \\
Chile & Indonesia & New Zealand & Singapore & Vietnam \\
China & Japan & Papua New Guinea & Solomon Islands & \\
\hline
\end{tabular}

Sections 1.2 and 8.2 of the Tokyo MOU and Sect. 1.1 of its Annex 1, entitled 'Membership of the Memorandum', stipulate that the Tokyo MOU applies to the "Asia-Pacific region", a term that is not further defined. The US Coast Guard has observer status with the Tokyo MOU and cooperates in a similar way as with the Paris MOU.

\section{Output of the Arctic Council}

The Arctic Council is a high-level forum established by means of the Ottawa Declaration (1996). The choice for a non-legally binding instrument is a clear indication that the Council was not intended to be an international organization

\footnotetext{
17 Information provided to the author by C. Droppers, Paris MOU Secretariat, on 25 Jan 2013.

18 Information provided to the author by C. Droppers, Paris MOU Secretariat, on 25 Jan 2013.
} 
and implies that the Council cannot adopt legally binding decisions or instruments. The Arctic SAR Agreement was therefore not adopted by the Council, even though it was negotiated under its auspices and the Council's May 2011 Ministerial Meeting was also used as the occasion for its signature.

The mandate of the Arctic Council is very broad and relates to "common Arctic issues" with special reference to "issues of sustainable development and environmental protection in the Arctic" (Ottawa Declaration 1996, art. 1). A footnote nevertheless specifies that the Council "should not deal with matters related to military security". Marine shipping falls squarely under this broad mandate and this is also subscribed by the fact that the Arctic Council has produced output that relates specifically to marine shipping as well less specific or more indirectly relevant output.

The latter includes the 2004 Arctic Marine Strategic Plan (AMSP; Arctic Council 2004), which was developed under PAME and is currently under revision, with adoption scheduled for the 2014 Deputy Ministerial Meeting (PAME 2012b). Both the Arctic SAR Agreement and the future Arctic MOPPR Agreement-scheduled to be signed at the 2013 Kiruna Ministerial Meetingcould be regarded to belong in this category as well. While both implement global IMO instruments-namely the SAR Convention and OPRC 90 -, the Arctic SAR Agreement also implements the ICAO Convention (1994), and neither deals exclusively with shipping incidents, but also with incidents relating to air traffic and offshore installations. Finally, much of the output of EPPR belongs in this category as well, as evidenced by EPPR's role in the negotiation process of the future Arctic MOPPR Agreement by developing Operational Guidelines that will be appended to the Agreement (EPPR 2012).

The most important Arctic Council output that focuses specifically on Arctic marine shipping is the AMSA, completed by PAME in 2009. The AMSA contains a considerable number of recommendations categorized under the headings 'Enhancing Arctic Marine Safety', 'Protecting Arctic People and the Environment', and 'Building the Arctic Marine Infrastructure'. At least three of these recommendations have already been implemented, namely Recommendation I(B), which includes support for the updating and mandatory application of the Arctic Shipping Guidelines; Recommendation I(E), which supports the negotiation of an Arctic SAR instrument; and Recommendation III(C), which supports, inter alia, the development of circumpolar agreements on environmental response capacity.

As Recommendation I(B) eventually shaped to a considerable extent-in addition to actions undertaken within the Antarctic Treaty System (ATS) - the decision to develop the IMO Polar Code, it is a good example of the Arctic Council's socalled 'decision-shaping' function (Molenaar 2012). This function continues to be relevant through PAME's continuous monitoring of progress with the implementation of the AMSA Recommendations.

New Arctic Council initiatives in the domain of Arctic marine shipping will probably arise from the Arctic Ocean Review (AOR) project that is currently 
carried out within PAME. Phase II of this project is intended to culminate in a final report adopted at the Council's May 2013 Kiruna Ministerial Meeting that will:

summarize potential weaknesses and/or impediments in the global and regional instruments and measures for [the] management of the Arctic marine environment; outline options to address these weaknesses and/or impediments; and, make agreed recommendations to help ensure a healthy and productive Arctic marine environment in light of current and emerging trends (AOR 2011).

The AOR Phase II draft Report (AOR 2013) contains a Chap. 3 on 'Arctic Marine Operations and Shipping', with specific opportunities (A-L) in Sect. 3.4.3, some of which build on the AMSA recommendations. Section 6.4 below incorporates some of these.

As the Polar Code will ultimately be adopted by the IMO, it will be regarded as that body's output and not as the Council's. The connection between the Polar Shipping Code and the Council is clearly very different from the connection between the Council and the Arctic SAR Agreement and the future Arctic MOPPR Agreement. This author has introduced the concept of the Arctic Council System (ACS) to clarify that legally binding instruments such as the Arctic SAR Agreement and the future Arctic MOPPR Agreement - and their institutional components - can be part of the Council's output even though they are not-and in fact could not be-formally adopted by it (Molenaar 2012).

The ACS concept consists of two basic components. The first component is made up of the Council's constitutive instrument - the Ottawa Declaration, other Ministerial Declarations, other instruments adopted by the Arctic Councilfor instance its Arctic Offshore Oil and Gas Guidelines (PAME 2009), and the Council's institutional structure. The second component consists of instruments 'merely' negotiated under the Council's auspices and their institutional components. The 2011 Arctic SAR Agreement and the Meetings of the Parties envisaged under its Article 10 belong to this category and the Arctic MOPPR Agreement and, if included, its institutional component, will soon be as well.

The AOR Phase II draft Report proposes recourse to the ACS approach in order to amend or complement the future Arctic MOPPR Agreement to ensure coverage of other pollutants - in particular noxious liquid substances-, as well as on the collection and sharing of Arctic marine traffic data (AOR 2013).

\section{Acts of the OSPAR Commission}

The spatial competence of the OSPAR Commission extends to the 'OSPAR Maritime Area', which includes areas within and beyond national jurisdiction (OSPAR Convention 1992, art. 1(a)). The OSPAR Maritime Area roughly overlaps with the Atlantic sector of the marine Arctic, but about half extends further south. Nothing in the OSPAR Convention or the Acts of the OSPAR Commission challenges IMO's primacy in the regulation of international merchant shipping, but also does not entirely preclude action in relation to merchant shipping. Article 4(2) of 
Annex $\mathrm{V}$ to the OSPAR Convention stipulates that Members of the OSPAR Commission can raise the need for regulatory action within IMO and requires them to cooperate among other things on regional implementation of IMO instruments. An example of action by the OSPAR Commission in the domain of shipping is the voluntary interim application of certain standards of the BWM Convention adopted in 2007. In 2012, this action was replaced by joint action between the OSPAR Commission and the regional seas bodies for the Baltic and Mediterranean Seas. ${ }^{19}$

\subsection{Gaps in the International Legal and Policy Framework and Options for Addressing them}

\subsubsection{Gaps}

Before identifying gaps in the international legal and policy framework for Arctic marine shipping, it is only fair to note that much progress has been made in addressing such gaps in the last five years or so. IMO managed to adopt the Polar Shipping Guidelines in 2009 and is working hard on the adoption of the Polar Code. The Arctic Council finalized AMSA in 2009 and has made good progress in implementing several of its recommendations, most notably culminating in the signature of the Arctic SAR Agreement in 2011 and the future Arctic MOPPR Agreement, scheduled to be signed in May 2013.

As the Polar Code is still to be adopted and enter into force, the following appear to be the main gaps in the international legal and policy framework for Arctic marine shipping:

1. Insufficient participation in relevant international instruments, for instance the LOS Convention - to which the US is not a party-and instruments such as the BWM Convention and the Arctic SAR Agreement, which are still to enter into force;

2. No dedicated, legally binding IMO standards for the marine Arctic, for instance in relation to discharge, emission, or ballast water exchange standards and CDEM (including fuel content (e.g., heavy fuel oil (HFO), anti-fouling, and ballast water treatment) standards;

3. No comprehensive mandatory or voluntary IMO ships' routeing system for all or part of the Arctic Ocean; and

4. No dedicated pan-Arctic mechanisms on monitoring, surveillance, inspection, and enforcement.

\footnotetext{
19 Joint Notice to Shipping from the Contracting Parties of the Barcelona Convention, OSPAR and HELCOM on: 'General Guidance on the Voluntary Interim Application of the D1 Ballast Water Exchange Standard by Vessels Operating between the Mediterranean Sea and the NorthEast Atlantic and/or the Baltic Sea' (Annex 17 to 2012 OSPAR Summary Record).
} 


\subsubsection{Options}

This subsection contains various options for addressing the gaps identified in the previous subsection. They are discussed under the following subsections: options for action within IMO; options for action outside IMO; and options for PSC initiatives. Some of the options for action outside IMO also highlight a potential role for the Arctic Council or the ACS approach.

\section{Options for Action Within IMO}

As the Polar Code is still under negotiation, the most obvious option for action within IMO is inclusion of the commonly used IMO standards mentioned under Gap No. 2 in Sect. 6.4.1 above. The desirability of restrictions on the use and carriage of $\mathrm{HFO}$ in the marine Arctic is under consideration within PAME as well. The negotiations on the Polar Code may also provide opportunities to include new types of standards, for instance compulsory pilotage and ice-breaker or tug assistance.

So far, there are no indications that navigation standards (ships' routeing measures, SRSs, and VTS) will be included in the Polar Code. Navigation standards could be adopted on a case-by-case basis as stand-alone standards, for instance a SRS or VTS for the Bering Strait, or speed restrictions for certain areas in order to avoid ship strikes of marine mammals or to reduce emissions. ${ }^{20}$ An alternative would be to develop a comprehensive ships' routeing system for part or all of the Arctic Ocean, which may be desirable in view of the continuous expansion of Arctic marine shipping. As the main shipping routes described in Sect. 6.2 resemble somewhat archipelagic sea lanes established pursuant to Article 53 of the LOS Convention, the procedure laid down in Article 53-implemented by Annex 2 to the IMO's General Provisions on Ships' Routeing-may be suitable as a model for developing 'Arctic Sea Lanes'. It is not a problem if one or more of these sea lanes would be partially on the high seas, as consensus-based IMO approval reflects support by the entire international community.

Designating one or more PSSAs with APMs in the marine Arctic is also an option that could be pursued in parallel with the Polar Code. Many of the abovementioned standards could be adopted as APMs. Area-based measures for the marine Arctic are also under consideration by PAME as part of the implementation of AMSA Recommendations II(A), (C), and (D) and the AOR project. It is disappointing — but to some extent understandable - that PAME decided to limit its efforts on PSSAs and MARPOL 73/78 special areas to the high seas of the Arctic Ocean (PAME 2012a; AOR 2013).

\footnotetext{
${ }^{20}$ See IMO doc. MEPC 60/4/24, of 15 Jan 2010, at para. 8, in the context of black carbon emissions. The MSC has adopted at least one speed restriction-albeit recommendatory and primarily for the purpose of human safety-, namely in the TSS "Between Korsoer and Sprogoe" (see IMO doc. MSC 78/26/Add.2, of 4 June 2004, at Annex 21, p. 8, n. 3 to the TSS).
} 


\section{Options for Action Outside IMO}

As was pointed out in Sect. 6.3.3, the LOS Convention does not preclude action outside IMO.

1. All states - in their capacities as flag states, port states, coastal states, or with regard to their tour operators - can encourage self-regulation by the (cruise) shipping industry;

2. All states, whether individually or collectively, can in their capacities as flag states impose standards on their vessels for shipping in the marine Arctic that are more stringent than GAIRAS, for instance special discharge, emission, and ballast water exchange standards or HFO standards. Such proactive steps can also be taken in anticipation of the entry into force of the Polar Code and other relevant IMO instruments and standards;

3. Arctic Ocean coastal states and other (Arctic) states - whether within or outside the scope of the Arctic Council or by pursuing the ACS approach—can, in their capacities as port states, develop a collective multifaceted strategy on port state jurisdiction for Arctic marine shipping. This strategy could consist of the following elements:

a. PSC initiatives (see 'Options for PSC initiatives' further below in this subsection);

b. Coordinated and optimized use of port state jurisdiction, for instance by implementing Article 218 of the LOS Convention in concert, exercising 'departure state jurisdiction', or using criminal or administrative law to impose charges such as furnishing false information or obstruction of inspection in connection with behaviour prior to entry into port (Molenaar 2007); and

c. Exercise of port state residual jurisdiction in concert in case the Polar Code takes too long to enter into force or its stringency level is deemed insufficient.

4. Arctic Ocean coastal states or Arctic states-whether within or outside the scope of the Arctic Council or by pursuing the ACS approach-could, in their capacities as coastal states, collectively

a. Amend or complement the future Arctic MOPPR Agreement to ensure coverage of other pollutants, in particular noxious liquid substances (AOR 2013);

b. Develop a new regional instrument on the collection and sharing of Arctic marine traffic data (AOR 2013);

c. Ensure regional implementation of IMO's Guidelines on Places of Refuge;

d. Develop a regional mechanism for coordinated aerial and satellite surveillance of intentional and accidental marine pollution;

e. Harmonize relevant domestic laws, regulations, and policies, including in relation to enforcement; and

f. Take other action consistent with international law, including by relying on Article 234 of the LOS Convention, in case the Polar Code takes too long to enter into force or its stringency level is deemed insufficient.

5. Canada, the Russian Federation, and key flag states could convene multilateral consultations on Arctic marine shipping in order to exchange views and address concerns on navigation in the Northwest Passage and the Northern Sea Route. 


\section{Options for PSC Initiatives}

PSC initiatives can either be undertaken within existing regional PSC Arrangements or by establishing a new Arrangement, namely an Arctic Ocean/region MOU.

As regards possible initiatives on Arctic marine shipping within existing Arrangements, one approach would be to bring as much Arctic marine shipping as possible under the scope of the Paris MOU. This would be based on the assumption that the stringency level and performance of the Paris MOU is the highest of all the regional PSC Arrangements. Accordingly, the Russian Federation could follow Canada's example (see Sect. 6.3.4 'Regional PSC Arrangements') by subjecting all its Pacific ports to the Paris MOU. The Paris MOU would thereby cover all intra-Arctic shipping and a sizeable part of trans-Arctic shipping, in particular if relatively much use would be made of transhipment ports in the high North Atlantic and the high North Pacific.

Further initiatives could be developed within the Paris MOU as well. As highlighted earlier, these would not relate to the prescription of new standards, but rather be concerned with harmonized and coordinated inspection, and corrective enforcement action with respect to existing standards. Initiatives should be specifically tailored to ships that have engaged in Arctic marine shipping since their last port visit and those that will do so before their next port visit. As regards the Paris MOU, adjustments could for instance be made to one or more Port State Control Committee Instructions (e.g., 'Guidance on Type of Inspections') to include special guidance/instructions for inspections of ships that have engaged or will engage in Arctic marine shipping, as well as specific requirements for the qualification and training of PSC officers in that regard. Such guidance could also be developed by, and made applicable to, a sub-set of the maritime authorities that participate in, or cooperate with, the Paris MOU.

But unless trans-Arctic shipping would make extensive use of transhipment ports in the high North Pacific, departure or destination ports in the Asia-Pacific region would still constitute a significant gap. Similar dedicated guidance/instructions on Arctic marine shipping could therefore be developed within the Tokyo MOU.

An alternative to developing initiatives under the Paris and Tokyo MOUs is the development of an Arctic Ocean/region MOU. As participation in regional PSC Arrangements is always reserved for maritime authorities of the region's coastal states, it follows that the maritime authorities from the following states would be participants: Denmark (Greenland), Canada, Norway, the Russian Federation, the US and-especially in case ships involved in Arctic marine shipping are expected to make extensive use of Icelandic ports-Iceland.

As noted in the discussion on Regional PSC Arrangements in Sect. 6.3.4, the maritime authorities from these states either already formally participate in, or cooperate with, both the Paris and Tokyo MOUs (Canada, the Russian Federation, ${ }^{21}$ and the US) or just the Paris MOU (Denmark (Greenland), Iceland, and Norway).

21 See also supra note 64 and accompanying text. Memorandum of Understanding on Port State Control in the Black Sea Region, Istanbul, 7 Apr 2000. In effect 19 Dec 2000, as regularly amended. Most recent text at <www.bsmou.org $>$. 
While the cost-effectiveness of all regional PSC Arrangements as a whole would not necessarily be negatively affected by further overlaps in participation, the six maritime authorities will have to weigh the costs of participating in, or cooperating with, yet another MOU against the benefits that its establishment would bring. This would seem to depend, among other things, on their views as to the need and urgency of dedicated PSC initiatives for Arctic marine shipping; the extent to which Arctic marine shipping is expected to be composed of intra-Arctic shipping and ships using transhipment ports in the high North Atlantic and the high North Pacific; and the prospects of adopting satisfactory dedicated PSC initiatives for Arctic marine shipping within the Paris or Tokyo MOUs (Stokke 2012).

\subsection{Potential for EU-US Cooperation}

A discussion on the potential for EU-US cooperation on Arctic marine shipping must acknowledge at the outset that whereas the US is an Arctic Ocean coastal state, the EU cannot rely on such a de facto capacity. Denmark is an Arctic Ocean coastal state with respect to Greenland and an Arctic coastal state with respect to the Faroe Islands, but Denmark's EU Membership does not extend to Greenland or the Faroe Islands (TFEU 2008, arts. 204 and 355(5)(a)). However, the EU can still act in various other de facto capacities; for instance as a flag state-pursuant to the various navigational rights applicable within the marine Arctic -, port state, or with respect to natural and legal persons of its Member States.

'Transport' and 'environment' are among the areas listed in Article 4(2) of the TFEU where the EU and its Member States share competence. This shared competence in shipping is among things reflected in the fact that the EU is not a member of IMO. The European Commission nevertheless has observer status with IMO.

Both the US and several EU Member States_-in particular Cyprus, Denmark, Germany, Greece, and Malta-are important actors in the domain of international merchant shipping on account of the number of vessels and cumulative deadweight tonnage registered under their flags or in terms of (beneficial) ownership over such vessels (UNCTAD 2011). More in general, seaborne trade is vital to the economies of the US and EU Member States and they also have a range of other interests that are closely associated with shipping (Raspotnik and Rudloff 2012). The high priority accorded to safeguarding navigational rights from undue interference also results from the naval capability of the US and several EU Member States and concerns that restrictions on merchant shipping may spill over to warships and other government ships. It is worth noting that the US Arctic Region Policy NSPD-66 (2009) discusses navigation rights and interests in Section III(B), entitled 'National Security and Homeland Security Interests in the Arctic'.

As regards merchant shipping in the marine Arctic, the US seems so far mainly involved in intra-Arctic traffic. Among the EU Member States, Denmark, Finland, and Germany are involved in both intra- and trans-Arctic shipping. Other EU Member States may also have an interest in Arctic marine shipping on account or their ports, for instance the Netherlands on account of Rotterdam. 
In addition to their shared shipping interests, the US and the EU share interests and obligations in relation to the Arctic marine environment and its marine biodiversity, including marine mammals. All these rights and interests of the EU and the US related or associated with Arctic shipping are reflected in various recent policy statements including the US Arctic Region Policy, the European Commission's Arctic Communication (European Commission 2008) and the EU Council conclusions on Arctic issues Council of the European Union (2009). For the purpose of this section, they are grouped together below under three headings, followed by various opportunities for bilateral cooperation derived in some cases from the options identified in Sect. 6.4.2:

1. Protection and preservation of the Arctic marine environment and its marine biodiversity:

a. Joint and coordinated engagement and support for the negotiations on the IMO Polar Code;

b. Joint efforts to ensure that the US and EU Member States have a reputation as responsible and high-performance shipping states, including by ensuring compliance with international obligations in all their capacities; and

c. Joint pro-active steps in their (de facto) capacities as flag states (see No. 2 under 'Options for action outside IMO' in Sect. 6.4.2).

2. Safeguarding navigational rights from undue interference:

a. Cooperation on monitoring the laws, regulations, and practices of Canada, the Russian Federation, and other Arctic states to verify consistency with the international law of the sea; and

b. Joint or coordinated diplomatic protests in case laws, regulations, or practices are not consistent with the international law of the sea.

3. Promoting multilateral regulation of Arctic marine shipping:

a. Joint and coordinated engagement within relevant international bodies, including the IMO, the Paris and Tokyo MOUs, and the Arctic Council;

b. Joint actions to initiate multilateral consultations on the Northwest Passage and the Northern Sea Route (see No. 5 under 'Options for action outside IMO' in Sect. 6.4.2);

c. Joint action to discourage unnecessary reliance on Article 234 of the LOS Convention, among other things by working towards a high stringency level of the IMO Polar Code and its speedy entry into force; and

d. Joint action to encourage regional harmonization of relevant laws, regulations, and practices, including in relation to enforcement.

\subsection{Conclusions}

In coming years, Arctic sea ice coverage and thickness are highly likely to gradually decrease and Arctic marine shipping to increase. In view of these trends, the international legal and policy framework for Arctic marine shipping cannot be assumed to be adequate. This is in fact broadly acknowledged as much progress 
has been made in addressing gaps in this framework during the last five years or so. The IMO managed to adopt the Polar Shipping Guidelines in 2009 and is working hard on the adoption of the Polar Code, even though this will not be achieved before 2014. The Arctic Council finalized AMSA in 2009 and has made good progress in implementing several of its recommendations, most notably culminating in the signature of the Arctic SAR Agreement in 2011 and the future Arctic MOPPR Agreement, scheduled to be signed in May 2013.

Many of the options suggested in Sect. 6.4.2 to address the gaps identified in Sect. 6.4.1 also offer opportunities for cooperation between the EU and the US. These opportunities can be grouped together under headings that reflect the rights and interests of the EU and the US related or associated with Arctic shipping in line with their recent policy statements, namely: protection and preservation of the Arctic marine environment and its biodiversity; safeguarding navigational rights from undue interference; and promoting multilateral regulation of Arctic marine shipping.

\section{References}

Agreement on Arctic Cooperation (1988) Agreement between the Government of Canada and the Government of the United States of America on Arctic Cooperation. Canada Treaty Series 1988, No. 29. Entered into force 11 Jan 1988

AMSA (2009) Arctic Marine Shipping Assessment 2009 Report. Arctic Council, Apr 2009

AMSA Scenarios (2008) The Future of Arctic Marine Navigation in Mid-Century. Scenario Narratives, Prepared for the Arctic Marine Shipping Assessment. May 2008

Antarctic Treaty (1959) The Antarctic Treaty, 1 Dec 1959, 402 U.N.T.S. 71. Entered into force 23 June 1961

Anti-Fouling Convention (2001) International Convention on the Control of Harmful Antifouling Systems on Ships, 5 Oct 2001, IMO Doc. AFS/CONF/26, of 18 Oct 2001. Entered into force 17 Sept 2008

AOR (2011) Phase I report (2009-2011) of the Arctic Ocean Review (AOR) project. $<$ www.pame.is>. Accessed 1 Feb 2013

AOR (2013) The Arctic Ocean Review Project. Phase II report 2011-2013, consolidated version of $9 \mathrm{Feb} 2013$. On file with author

Arctic Council (2004) Arctic Marine strategic Plan. 24 Nov 2004. Available at <http://www.pame. is/images/stories/AMSP_files/AMSP-Nov-2004.pdf>. Accessed 5 Feb 2013

Arctic MOPPR Agreement (2013) Agreement on Cooperation on Marine Oil Pollution Preparedness and Response in the Arctic, scheduled to be signed at the Arctic Council's Ministerial Meeting in Kiruna, May 2013

Arctic SAR Agreement (2011) Agreement on Cooperation on Aeronautical and Maritime Search and Rescue in the Arctic, 12 May 2011, 50 I.L.M. 1119 (2011). Entered into force on 19 Jan 2013

Arctic Shipping Guidelines (2002) Guidelines for Ships Operating in Arctic Ice-Covered Waters, IMO MSC/Circ. 1056, MEPC/Circ. 399, 23 Dec 2002

AWPPA (1970) Arctic Waters Pollution Prevention Act 1970, R.S.C. 1985, Canada

Bartenstein K (2011) The "Arctic Exception" in the Law of the Sea Convention: a Contribution to Safer Navigation in the Northwest Passage? Ocean Dev Int Law 42:22-52

Black Sea MOU (2000) Memorandum of Understanding on Port State Control in the Black Sea Region, Istanbul, 7 Apr 2000. Entered into force 19 Dec 2000, as regularly amended 
Brigham LW (2010) Think again: The Arctic. Foreign Policy, Sept/Oct. 2010

Brubaker RD (1999) The Legal Status of the Russian Baselines in the Arctic. Ocean Dev Int Law 30:191-233

Brubaker RD (2001) Straits in the Russian Arctic. Ocean Dev Int Law 32:263-287

Brubaker RD (2005) The Russian Arctic Straits. Martinus Nijhoff, Leiden

Bunker Oil Convention (2001) International Convention on Civil Liability for Bunker Oil Pollution Damage, 23 Mar 2001, LEG/CONF.12/19. Entered into force 21 Nov 2008

BWM Convention (2004) International Convention for the Control and Management of Ships' Ballast Water and Sediments, 13 Feb 2004. Not in force, IMO Doc. BWM/CONF/36, of 16 Feb 2004

Canada Shipping Act (2001) S.C. 2001, c. 26

Chircop A (2009) The Growth of International Shipping in the Arctic: Is a Regulatory Review Timely? Int J Marine Coastal Law 24:355-380

Civil Liability Convention (1969) International Convention on Civil Liability for Oil Pollution Damage, Brussels, 29 Nov 1969, 9 I.L.M. 45 (1970). Entered into force 19 June 1975. Replaced and entered into force 30 May 1996

COLREG 72 (1972) Convention on the International Regulations for Preventing Collisions at Sea, 20 Oct 1972, 1050 U.N.T.S. 16. Entered into force 15 July 1977

Council of the European Union (2009) Council Conclusions on Arctic issues, In: 2985th Foreign Affairs Council Meeting, 8 Dec 2009

CYIL (1987) Canadian Yearbook of International Law, Vol. 25. University of British Columbia Press, Victoria

CYIL (1988) 26 Canadian Yearbook of International Law, Vol. 26. University of British Columbia Press, Victoria

Directive on Port State Control (2009) Directive 2009/16/EC of the European Parliament and of the Council of 23 Apr 2009 on port State control, 2009 O.J. (L 131/57) (23 Apr 2009)

Emmerson C (2011) Russia's Arctic Opening. Foreign Policy 30 Mar 2011. $<$ http://www.foreignpolicy.com/articles/2011/03/30/russias_arctic_opening >

EPPR (2012) EPPR Progress report to Senior Arctic Officials; ACSAO-SE03 Haparanda, Doc 6.1

European Commission (2008) Communication from the Commission to the European Parliament and the Council. The European Union and the Arctic Region, 20 Nov 2008, COM(2008) 763

Franckx E (1993) Maritime Claims in the Arctic: Canadian and Russian Perspectives. Martinus Nijhoff Publishers, Dordrecht

Fund Convention (1971) International Convention on the Establishment of an International Fund for Compensation for Oil Pollution Damage, 18 Dec 1971, 11 I.L.M. 284 (1972). Entered into force 16 Oct 1978

Hakapää K (1981) Marine Pollution in International Law: Material Obligations and Jurisdiction. Suomalainen Tiedeakatemia, Helsinki

HNS Convention (1996) International Convention on Liability and Compensation for Damage in Connection with the Carriage of Hazardous and Noxious Substances by Sea, 3 May 1996, 35 I.L.M. 1406. Not in force

HNS Protocol (2000) Protocol on Preparedness, Response and Co-operation to Pollution Incidents by Hazardous and Noxious Substances, 15 Mar 2000, IMO Doc. HNSOPRC/CONF/11/Rev.1, of 15 Mar 2000. Entered into force 14 June 2007

Huebert R (2001) Article 234 and Marine Pollution Jurisdiction in the Arctic. In: Oude Elferink AG, Rothwell DR (eds) The Law of the Sea and Polar Maritime Delimitation and Jurisdiction. Martinus Nijhoff Publishers, New York, pp 249-267

Humpert M, Raspotnik A (2012) The Future of Arctic Shipping Along the Transpolar Sea Route. Arctic Yearbook 2012:281-307

ICAO Convention (1994) Convention on International Civil Aviation, Chicago, 7 Dec 1944, 15 U.N.T.S. 295 (1948). Entered into force 4 Apr 1947

ICS (2012) Position Paper on Arctic Shipping. International Chamber of Shipping. <www.icesshipping.org >. Accessed 1 Feb 2013 
IMO (1985) General Provisions on Ships' Routening. IMO Resolution A.572(14). Adopted on 20 Nov 1985, as amended

IMO (1999) Guidelines for voyage planning. IMO Doc. A 21/Res.893, 4 Feb 2000. Adapted on 25 Nov 1999

IMO (2001) Guidelines for the Designation of Special Areas under MARPOL 73/78', as set out in Annex 1 to IMO Assembly Resolution A.927(22) 2001, to be revoked in 2013 by means of an IMO Assembly Resolution (see IMO Doc. 63/23/Add.1, 14 Mar 2012, Annex 27)

IMO (2005) IMO Assembly Resolution A. 982(24) of 1 Dec 2005, 'Revised Guidelines for the Identification and Designation of Particularly Sensitive Sea Areas' (IMO doc. A 24/Res.982, 6 Feb 2006)

IMO (2008) Guidelines on voyage planning for passenger ships operating in remote areas. IMO Doc. A 25/Res.999, 3 Jan 2008. Adapted on 29 Nov 2007

Kingdom of Denmark (2011) Denmark, Greenland and the Faroe Islands: Kingdom of Denmark Strategy for the Arctic 2011-2020. <www.nanoq.gl>. Accessed 29 Jan 2013

Kraska J (2007) The Law of the Sea Convention and the Northwest Passage. Int J Marine Coastal Law 22:257-282

Lalonde S (2004) Increased Traffic Through Canadian Arctic Waters: Canada's State of Readiness. Revue Juridique Themis 38:49-124

LOS Convention (1982) United Nations Convention on the Law of the Sea, 10 Dec 1982, 1833 U.N.T.S. 396. Entered into force 16 Nov 1994

Lowe AV (1977) The Right of Entry into Maritime Ports in International Law. San Diego Law Rev 14:597-622

MARPOL 73/78 (1973/1978) International Convention for the Prevention of Pollution from Ships, 2 Nov 1973, 2 I.L.M. 1319 (1973), as modified by the 1978 Protocol Relating to the International Convention for the Prevention of Pollution from Ships (17 Feb 1978, 17 I.L.M. 546 (1978)) and the 1997 Protocol to Amend the International Convention for the Prevention of Pollution from Ships (26 Sept 1997) and as regularly amended. Entry into force varies for each Annex. At the time of writing Annexes I-VI were all in force

McDorman TL (2010) The Northwest Passage: International Law, Politics and Cooperation. In Nordquist MH, Heidar TH, Moore JN (eds) Changes in the Arctic Environment and the Law of the Sea, Martinus Nijhoff Publishers, Dordrecht, pp 227-250

McDorman TL (2012) National Measures for the Safety of Navigation in Arctic Waters: NORDREG, Article 234 and Canada. In Nordquist MH, Moore JN, Soons AHA, Kim H (eds) The Law of the Sea Convention. US Accession and Globalization. Martinus Nijhoff Publishers, Leiden

McDorman TL (2013) Canada, the United States and International Law of the Sea in the Arctic Ocean. In VanderZwaag D, Stephens T (eds) Polar Oceans Governance in an Era of Environmental Change. Edward Elgar, Cheltenham

McRae D (1987) The Negotiation of Article 234. In: Griffiths F (ed) Politics of the Northwest Passage. McGill-Queen's University Press, Kingston and Montreal, pp 98-114

Minister of Indian Affairs and Northern Development (2009) Canada's Northern Strategy: Our North, Our Heritage, Our Future, Ottawa

Molenaar EJ (1998) Coastal State Jurisdiction Over Vessel-Source Pollution. Kluwer Law International, The Hague

Molenaar EJ (2007) Port State Jurisdiction: Toward Comprehensive, Mandatory and Global Coverage. Ocean Dev Int Law 38:225-257

Molenaar EJ (2010) Arctic Marine Shipping. Overview of the International Legal Framework, Gaps and Options. J Trans Law Policy 18:289-325

Molenaar EJ (2012) Current and Prospective Roles of the Arctic Council System within the Context of the Law of the Sea. Int J Marine Coastal Law 27:553-595

Molenaar EJ, Hodgson S, VanderZwaag D, Heidar Hallsson H, Henriksen T, Holm-Peterson L, Vladimirovich Korel'skiy M, Kraska J, Már Magnússon B, Rolston S, Serdy A (2010) Legal Aspects of Arctic Shipping. Report commissioned by the European Commission, Directorate-General Maritime Affairs \& Fisheries, Feb 2010. On file with author 
NSPD-66 (2009) National Security Presidential Directive and Homeland Security Presidential Directive. Arctic Region Policy, 9 Jan 2009, NSPD-66/HSPD-25

OPRC 90 (1990) International Convention on Oil Pollution Preparedness, Response, and Cooperation, 30 Nov 1990. 30 I.L.M. 733 (1991). Entered into force 13 May 1995

Ottawa Declaration (1996) Declaration on the Establishment of the Arctic Council, 19 Sept 1996, 35 I.L.M. 1382

PAME (2009) Arctic Offshore Oil and Gas Guidelines. Last updated 29 Apr 2009

PAME (2012a) PAME Working Group Meeting Report No: I-2012. 26-27 Mar 2012, Sweden

PAME (2012b) Record of Decisions and Follow-up Actions. PAME II-2012. 18-20 Sept 2012

Paris MOU (1982) Memorandum of Understanding on Port State Control, Paris, 26 Jan 1982. Entered into force 1 July 1982, as regularly amended. This chapter uses the version that includes the 34th amendment and entered into force on 1 July 2012

Pharand D (2007) The Arctic Waters and the Northwest Passage: a Final Revisit. Ocean Dev Int Law 78:3-69

Polar Shipping Guidelines (2009) Guidelines for ships operating in polar waters, IMO Assembly Resolution A.1024(26), 2 Dec 2009

Protocol on Environmental Protection (1991) Protocol on Environmental Protection to the Antarctic Treaty. Annexes I-IV, 4 Oct 1991. Entered into force 14 Jan 1998; Annex V (adopted as Recommendation XVI-10), 17 Oct 1991. Entered into force 24 May 2002; Annex VI (adopted as Measure 1(2005)), 14 June 2005. Not in force

Raspotnik A, Rudloff B (2012) The EU as a shipping actor in the Arctic. characteristics, interests and perspectives. Working Paper FG 2, 2012/Nr. 4 Dec 2012, SWP Berlin

Roach JA, Smith RW (1996) United States Responses to Excessive Maritime Claims, 2nd edn. Martinus Nijhoff Publishers, The Hague

Rothwell DR (1996) The Polar Regions and the Development of International Law. Cambridge University Press, Cambridge

SAR Convention (1979) International Convention on Maritime Search and Rescue, 27 Apr 1979. 1405 U.N.T.S. 118. Entered into force 22 June 1985

Sen. Exec. Rep. 110-9 (2007) United States Senate Executive Report 110-9: Convention on the Law of the Sea. In: 110th Congress, 19 Dec 2007

SOLAS 74 (1974) International Convention for the Safety of Life at Sea, 1 Nov 1974, 1184 U.N.T.S. 278. Entered into force 25 May 1980

Solski J (2013) New Legal Developments in the Russian Regulation of Navigation in the Northern Sea Route. Arctic Rev Law Politics, pp 90-120

Spitsbergen Treaty (1920) Treaty concerning the Archipelago of Spitsbergen, 9 Feb 1920, 2 L.N.T.S. 7. Entered into force 14 Aug 1925

STCW 78 (1978) International Convention on Standards of Training, Certification and Watchkeeping for Seafarers, 1 Dec 1978, 1361 U.N.T.S. 2 Entered into force 28 Apr 1984. As amended and modified by the 1995 Protocol

Stokke OS (2012) Regime interplay in Arctic shipping governance: explaining regional niche selection. Int Environ Agree Politics Law Econ 13(1):65-85

TFEU (2008) Treaty on the Functioning of the European Union. Consolidated Version. O.J. C $115 / 47$

Tokyo MOU (1993) Asia-Pacific Memorandum of Understanding on Port State Control in the AsiaPacific Region, Tokyo, 1 Dec 1993. Entered into force effect 1 Apr 1994, as regularly amended. This chapter uses the version that includes the 12th amendment and in effect on 1 June 2012

Tymchenko L (2001) The Northern Sea Route: Russian Management and Jurisdiction Over Navigation in Arctic Seas. In: Oude Elferink AG, Rothwell DR (eds) The law of the sea and polar maritime delimitation and jurisdiction. Martinus Nijhoff Publishers, The Hague, pp 269-291

UNCTAD (2011) Review of Maritime Transport. In: United Nations Conference on Trade and Development. doc. UNCTAD/RMT/2011

VanderZwaag D et al (2008) Governance of Arctic Marine Shipping. Report prepared for the AMSA. Marine \& Environmental Law Institute, Dalhousie University, Halifax 